\title{
Electric energy consumption of milking process on some Finnish dairy farms
}

\author{
Mari Rajaniemi, Tapani Jokiniemi, Laura Alakukku and Jukka Ahokas \\ Department of Agricultural Sciences, University of Helsinki, Koetilantie 5, P.O. Box 28, FI-00014 University of Helsinki, Finland
}

e-mail: mari.rajaniemi@helsinki.fi

\begin{abstract}
The aim of this study was to examine the electric energy consumption of milking process on dairy farms and to evaluate the methods to improve the energy efficiency. The electricity consumption of the milking process was measured on three dairy farms in Southern Finland, and it varied between $37-62 \mathrm{Wh} \mathrm{kg}^{-1}$ milk. The largest energy saving potential was identified in milk cooling and the heating of cleaning water. Even simple methods, such as placing the condenser of the refrigeration system outside, may reduce the energy consumption of milk cooling by $30 \%$. Efficient milk pre-cooling can reduce the energy consumption of the whole milking process by more than $25 \%$. Even larger energy savings are possible with a sophisticated milk cooling - water heating systems. It was concluded that there is a significant potential to reduce the energy consumption and energy costs of the milking process, and thus to improve the profitability and sustainability of the sector at the same time.
\end{abstract}

Key words: electric energy consumption, efficiency, dairy farming, milking process

\section{Introduction}

The share of energy costs of the total costs in agriculture has increased during recent decades mainly due to the rise in energy prices, but also due to increased mechanisation and automatization on farms. In 2000, energy costs in Finnish agriculture accounted for $4.8 \%$ of the total costs, while in 2013 the corresponding figure was 7.3\% (Luonnonvarakeskus 2016). The prices of electricity and light fuel oil have roughly doubled during the same time frame (Finnish Energy Authority 2016, Petroleum \& Biofuels Association - Finland 2016).

Dairy farming is a particularly intensive consumer of electric energy (Tike 2010). Large amounts of electricity are used in milking, milk cooling and heating of cleaning water (Hörndahl 2008). In 2010, dairy farming was responsible for ca. $30 \%$ of the total direct energy consumption of the Finnish agriculture and horticulture sector. Direct energy consumption includes heating and electricity consumption of farm buildings, grain drying and machinery fuel consumption. Furthermore, it was the second largest electric energy consumer after greenhouse production (Tike 2010). Total direct energy consumption on Finnish dairy farms was 3.08 TWh in 2010 and electric energy consumption was ca. 0.46 TWh (15\% of total direct energy consumption). While the national milk production in the same year accounted to 2202 million kilograms (Tike 2013), the specific electric energy consumption was 0.20 $\mathrm{kWh} \mathrm{kg}^{-1}$ milk, when the total electricity consumption (3.08 TWh) of dairy farms is considered. The energy savings are, however, essential in all industry sectors in order to achieve the commonly agreed energy saving targets, and in farming sector in particular to improve the profitability of the sector.

Several studies have indicated that the major electric energy consuming processes in cow houses are milking, milk cooling and heating of cleaning water, together referred as the "milking process" (Brooks 1989, Peebles et al. 1993, Hörndahl 2008, Murgia et al. 2008, Upton et al. 2013). Peebles et al. (1994) noted that these operations also offer the most significant potential for electric energy savings and cost reductions. The electricity consumption of the milking process varied between studies. Hörndahl (2008) measured detailed energy consumption on two dairy farms in Sweden. He observed that milking and milk cooling were the largest electricity consumers in the milking process. Upton et al. (2013) measured electricity consumption on 22 Irish dairy farms, concluding that milk cooling and water heating were the largest electric energy inputs. Peebles et al. (1994) reported that the relative proportions of electric energy consumption in water heating and milk cooling vary according to the farm size. Cleaning of the milking system requires roughly the same amount of hot water regardless of the number of cows or amount of milk produced, while the electricity demand of milk cooling increases proportionally with the milk yield. Therefore the relative share of energy consumption in milk cooling increases with respect to water heating when the amount of milk produced increases (Peebles et al. 1994). 
Another significant energy consumers in cow houses are lighting, ventilation and feeding (Neuman 2009). According to Neuman (2009), on some farms, lighting may consume as much or even more electricity than milking. This situation will, however, probably change as the LED lights gradually replace less energy efficient lighting systems. Electricity consumption of ventilation will also become less significant, as natural ventilation has already become common in newly constructed Finnish cow-houses (Heimonen et al. 2012). Energy consumption of feeding, as well as the form of energy used (diesel or electricity), varies greatly between farms due to the large number of different available technologies. Other processes, such as manure removal, form usually relatively small part of energy consumption (Neuman 2009).

Improved energy efficiency offers possibilities to simultaneously reduce the GHG emissions and energy costs of production, creating benefits for both farmers and the environment. In order to improve the energy efficiency of the dairy system, energy consumption and its distribution between subsystems must be examined. Based on this information, improvements in energy efficiency can be planned and realized. This study focused on the electric energy consumption of the milking process, which is usually the largest, and also the most constant energy consumer in cow houses (Neuman 2009). The objective of the study was not only to examine the electricity consumption of milking process but, based on the results, to find and evaluate concrete methods to improve the electric energy efficiency of the dairy farming sector for more profitable and sustainable milk production.

\section{Material and methods \\ Information on the cow houses of the case farms}

Electricity consumption measurements were conducted on three dairy farms in Southern Finland (latitudes $60^{\circ}-$ $61^{\circ} \mathrm{N}$ ) under practical operating conditions. Background information on the cow houses is presented in Table 1. Farm I, II and III had 72, 83 and 91 cows, respectively. In 2014, the average number of cows on Finnish dairy farms was ca. 31 and the average annual milk yield was $8200 \mathrm{~kg}$ per cow (Luonnonvarakeskus 2016), which means that the case farms were considerably larger compared to the Finnish average. However, they were fairly representative sample of modern Finnish dairy farms.

Table 1. Background information on the cow houses

\begin{tabular}{|c|c|c|c|}
\hline & Farm I & Farm II & Farm III \\
\hline Type of house & Freestall & Freestall & Freestall \\
\hline Number of cows ${ }^{1)}$ & 72 & 83 & 91 \\
\hline Total milk yield $(\mathrm{kg})$ per year & 701500 & 874400 & N.A. \\
\hline Milk yield ${ }^{2)}$ & 10400 & 10535 & 9108 \\
\hline Milking system & $\begin{array}{l}\text { Robot (single-stall, Lely } \\
\text { Astronaut A3) }\end{array}$ & $\begin{array}{l}\text { Milking parlour, DeLaval, } \\
\text { herrigbone } 2 \times 6\end{array}$ & $\begin{array}{c}\text { Milking parlour, Westfalia } \\
\text { autotandem } 1 \times 4\end{array}$ \\
\hline Cleaning system & & DeLaval C200 & DeLaval C200 \\
\hline Milking events per day & 2.3 & 2 & 2 \\
\hline $\begin{array}{l}\text { Model and capacity of bulk } \\
\text { milk tank (litres) }\end{array}$ & Wedholms, 5000 & $\begin{array}{l}\text { Wedhoms } 5000 \text { with heat } \\
\text { recovery system }\end{array}$ & Wedholms 6000 \\
\hline Measuring period & October 2011 - July 2014 & March 2013 - February 2014 & $\begin{array}{c}\text { June } 2014 \text { - November } \\
2014\end{array}$ \\
\hline
\end{tabular}

Approximate average number of lactating cows; ${ }^{2)}$ Kilograms per cow per year.

Farm I had an automatic milking system (AMS), while farm II had herringbone and farm III autotandem milking stations. The vacuum pumps of milking stations in farms II and III did not utilize variable-frequency drives. Cows were milked 2 times per day on farms II and III and on average 2.3 times per day on farm I.

The bulk milk tanks on all of the farms were direct expansion tanks. Milk was cooled to a temperature of around 4 ${ }^{\circ} \mathrm{C}$ from the initial temperature of ca. $32{ }^{\circ} \mathrm{C}$. None of the case farms utilized milk pre-cooling system. Heat recovery from the milk cooling system was only used on farm II. The heat recovery system collected heat from milk cooling for heating the cleaning water. The bulk milk tanks were owned by the dairy cooperative and maintenance of the 
refrigeration system was included in the contract. The condensers of the refrigeration system were cleaned during annual maintenance if it was necessary. Milk was collected by the dairy every second day.

Cleaning water was heated in electric boilers on all farms. Farm II generated part of the energy for water heating with the heat recovery system from the milk cooling process. On farm I, the electricity used to heat the cleaning water of the milking system is included in the electricity consumption of the AMS system, and it is therefore presented under "milking". Therefore only the cleaning water of the bulk milk tank was heated in an electric boiler on farm I. Farm I had three main cleanings per day, while two cleanings occurred on farms II and III.

\section{Measurement setup and data analysis}

The electricity consumption of milking, milk cooling, and water heating was measured on all three case farms. On farm II, the total energy consumption of the cow house was also measured. Instrumentation of measurements is presented in Table 2. The electricity consumption measurements were continuous and data were recorded as the cumulative energy consumption ( $\mathrm{kWh}$ ) from the power meter pulses with a HOBO Pendant event data logger (Onset, USA). The measured electricity consumptions were converted to specific electric energy consumption (Wh kg-1 milk), which is a good indicator for the energy efficiency of the production.

The ambient temperature of the tank room was only measured on farm I. Linear correlation analysis was performed to determine the relationships between the specific electric energy consumption (Wh $\mathrm{kg}^{-1} \mathrm{milk}$ ) of the examined tasks and variables such as the milk yield, number of cows and temperature of the tank room. The categorization of Dansey and Reidy (2004) (1 perfect, 0.7-0.9 strong, 0.4-0.6 moderate, 0.1-0.3 weak) was used to classify the degree of correlation.

Table 2. Instrumentation used in measurements

\begin{tabular}{|c|c|c|}
\hline Measured value & Instrumentation & Logging interval \\
\hline Electricity consumption & $\begin{array}{l}\text { CTSCM } 40-100 / 5 \text { current transformer } \\
\text { (Howard Butler Ltd, England) } \\
\text { 3-phase Entes EPR-04S digital power } \\
\text { meter (Entes, Turkey) } \\
\text { HOBO Pendant event data logger } \\
\text { (Onset, USA) }\end{array}$ & Continuous measurement \\
\hline Temperature of tank room & HOBO Pendant data logger (Onset, USA) & 10 minutes \\
\hline
\end{tabular}

Data were collected from October 2011 to July 2014 on farm I, from March 2013 to February 2014 on farm II and from June 2014 to November 2014 on farm III (Table 1). The monthly milk production data was received from the bookkeeping of each farm, and by combining this information with the measured electric energy consumption, the specific electric energy consumption ( $\mathrm{Wh} \mathrm{kg}^{-1} \mathrm{milk}$ ) of the milking process was calculated. The measuring period on farm III was relatively short due to upcoming renovation and extension, which would have distorted the results. The data collected from the farm III should however be valid, since the measuring period contained both summer and winter months.

\section{Theoretical assessments}

When the energy consumption of the milking processes on the case farms had been investigated by measurements, theoretical assessments were made in order to examine the achievable energy saving potential. These assessments were made in milk cooling and water heating, including efficiency of the refrigeration system, precooling of milk with well water and heat recovery from the milk cooling process for water heating. For a comprehensive analysis, a detailed simulation of these dynamic systems would be required, which would be a topic for another paper. The aim of the analysis accomplished here was to gain a rough estimation of the achievable energy savings with the examined methods. 


\section{Performance of the refrigeration system}

In milk cooling, the essential key figure is the coefficient of performance (COP) of the refrigeration system. This can be determined from the heat energy that needs to be extracted from milk and the electric energy consumption of the refrigeration system:

$$
\varepsilon=\frac{Q}{W}
$$

where $\varepsilon=$ COP of the refrigeration system (dimensionless); $Q=$ heat energy extracted from milk (kJ); $W=$ electric energy consumption of the refrigeration system $(\mathrm{kJ})$.

The heat energy that needs to be extracted from milk $(Q)$ can be calculated with Equation 2:

$$
Q=c m_{m} \Delta T
$$

where $c=$ specific heat capacity of milk $\left(3.93 \mathrm{~kJ} \mathrm{~kg}^{-1} \mathrm{~K}^{-1}\right) ; m_{m}=$ amount of milk $(\mathrm{kg}) ; \Delta T=$ temperature difference in cooling process (typical value $33 \mathrm{~K}$ ).

The effect of the tank room temperature on the energy efficiency of the milk cooling process can be theoretically evaluated with the aid of the Carnot process, which sets the theoretical limits for the COP of any heat pump application. A Carnot heat pump cannot be built in practice, and the COP of practical heat pump applications is significantly lower compared to the Carnot process, but it helps to understand the factors influencing the performance of actual heat pumps (Perttula 2000). According to the Carnot theorem, the maximum COP $\left(\varepsilon_{\text {carnot }}\right)$ for any refrigeration system is:

$$
\varepsilon_{\text {carnot }}=\frac{T_{\text {source }}}{T_{\text {sink }}-T_{\text {source }}}
$$

where $T_{\text {source }}=$ temperature of heat source (milk) $(\mathrm{K}) ; T_{\text {sink }}=$ temperature of the heat sink (tank room or other environment of the condenser) (K).

It must be noted that $\varepsilon_{\text {carnot }}$ can only be calculated when $T_{\text {source }}$ is lower than $T_{\text {sink' }}$, since the heat pump is expected to transfer heat against the temperature gradient. If $T_{\text {source }}^{\text {source }}$ is higher than $T_{\text {sink, }}$, the heat transfer would occur naturally, and no heat pump would be needed. In the milk cooling process, the initial milk temperature is usually higher than the tank room temperature, and the COP for the Carnot process can only be calculated for the period when the milk has been cooled below the surrounding room temperature.

\section{Milk pre-cooling with well water}

The effect of pre-cooling on the energy efficiency of the milk cooling process can be evaluated by the temperature drop of milk in the heat exchanger of the pre-cooler, which reduces the energy requirement of the refrigeration system in final cooling. An average value of $36^{\circ} \mathrm{C}$ can be used as the temperature of milk and $6{ }^{\circ} \mathrm{C}$ as the temperature of well water (Turunen 2013). Efficiencies of heat exchangers in the pre-cooling systems vary from $60 \%$ to $85 \%$, according to the information provided by manufacturers (Sanford 2003, DeLaval 2016). The benefit from pre-cooling is, however, complicated to calculate accurately, since the COP of the refrigeration system constantly changes during the final cooling process, depending on the temperature difference between the heat source and sink. The latter part of the cooling process, when the temperature difference between milk and the tank room air is at the largest, consumes relatively more energy, and the cooling energy saved by the pre-cooling is thus not directly proportional to the temperature drop of milk in the pre-cooler. On the other hand, when pre-cooling is utilized, less heat energy is released to the air of the tank room, which lowers the tank room temperature and improves the COP of the refrigeration system. Due to the several variables and interactions in the process, only a rough estimation of the energy saving potential by pre-cooling of milk can be given.

\section{Heat recovery from milk cooling}

The energy saving potential of water heating using heat recovery from the milk cooling process can be estimated from the recoverable heat energy. The recoverable energy is often limited by the demand for hot water. Moreover, the economically achievable temperature limits the heat recovery potential, since the COP of the refrigeration 
system decreases when the temperature of the condenser increases. Therefore, heat recovery systems usually heat the water to a temperature of $\mathrm{ca} .50-52{ }^{\circ} \mathrm{C}$, and the heat recovery efficiency from the refrigerant to water is around 50\% (Turunen 2013). The rest of the extracted heat energy is released into air, and the final heating of water, depending on the intended use, is carried out by electrical resistors. The net amount of extracted heat energy can be calculated with Equation 2. In addition to energy savings in water heating, the heat recovery system reduces the energy consumption of the refrigeration system by lowering the temperature in the tank room, as part of heat energy extracted from milk is transferred into water instead of the tank room air.

\section{Combined pre-cooling and heat recovery}

Milk pre-cooling and heat recovery from milk cooling offer a quite similar energy saving potential, pre-cooling in the milk cooling process and heat recovery in heating of cleaning water. The use of both of these systems at the same time is not necessarily rational, since pre-cooling reduces the amount of economically recoverable heat energy in milk. If heat recovery would be applied after pre-cooling, the COP of the refrigeration system would be poor and the amount of heat energy would not necessarily be sufficient. Corscadden et al. (2014) developed a theoretical model for milk pre-cooling and heat recovery for water heating and validated the model results with measurements from farms. They concluded that the combination of milk pre-cooling and heat recovery was only slightly more energy efficient than either of these systems used alone, and for smaller farms (milk yield $<700000$ I $a^{-1}$ ) the most profitable option was to use the heat recovery system alone. Also Peebles et al. (1994) noted in their study with transient computer model of milk cooling and water heating, that heat recovery alone is more suitable for smaller farms. The crucial factor is the ratio between the energy consumption of milk cooling and water heating: if milk cooling uses more energy than water heating, the greatest energy savings can be achieved by milk pre-cooling, and vice versa. However, Peebles at al. (1994) concluded that on large farms (200 or 400 cows) the best option considering the energy savings is combined pre-cooling and heat recovery.

\section{Results and discussion \\ Electricity consumption of milking, cooling and water heating}

The specific electric energy consumption of milking, milk cooling and water heating (milking process) on the case farms is presented in Table 3. The total specific electric energy consumption varied from 37 to $62 \mathrm{Wh} \mathrm{kg}^{-1} \mathrm{milk}$ Milk cooling was the largest energy input of the milking process on farms II and III. Farm II was the most energy efficient considering the whole milking process, mainly due to the lower electricity consumption in water heating and milking. The monthly variation in the total electricity consumption of the milking process was moderate, as the relative standard deviation (RSD) was $13 \%, 5.4 \%$ and $9.6 \%$ on the farms I, II and III respectively. Monthly variation was largest on farm I, which utilized AMS, and milking was responsible for major part of this variation (Table 3).

\begin{tabular}{|c|c|c|c|}
\hline & \multicolumn{3}{|c|}{ Specific electric energy consumption, Wh kg-1 milk } \\
\hline & Farm I & Farm II & Farm III \\
\hline Milking mean & $29.3^{1)}$ & 9.1 & 14.9 \\
\hline SD & $6.3^{1)}$ & 0.5 & 2.7 \\
\hline Milk cooling mean & 21.9 & 18.5 & 24.9 \\
\hline SD & 1.8 & 1.6 & 1.5 \\
\hline Water heating mean & 2.2 & 9.7 & 22.8 \\
\hline SD & 0.6 & 1.3 & 2.3 \\
\hline In total mean & 54.3 & 37.3 & 62.6 \\
\hline SD & 7.1 & 2.0 & 6.0 \\
\hline
\end{tabular}

Total electric energy consumption in the cow house was only measured on farm II. Figure 1 presents the total monthly electric energy consumption in the cow house and the electricity consumption of the milking process on farm II. 
The milking process accounted on average for approximately $48 \%$ of the total electric energy consumption in the cow house. The total energy consumption was lowest in summer, when the cows were grazing for part of the time. However, the electricity consumption of the milking process remained relatively constant throughout the year. This indicates that, in addition to the milking process, also other tasks, such as lighting the cow house and heating of social- and office premises and the milking parlour during the cold and dark periods of the year, form a significant part of the total electricity consumption. In winter months, this other energy consumption was actually ca. 1.5 times greater than that of the milking process.

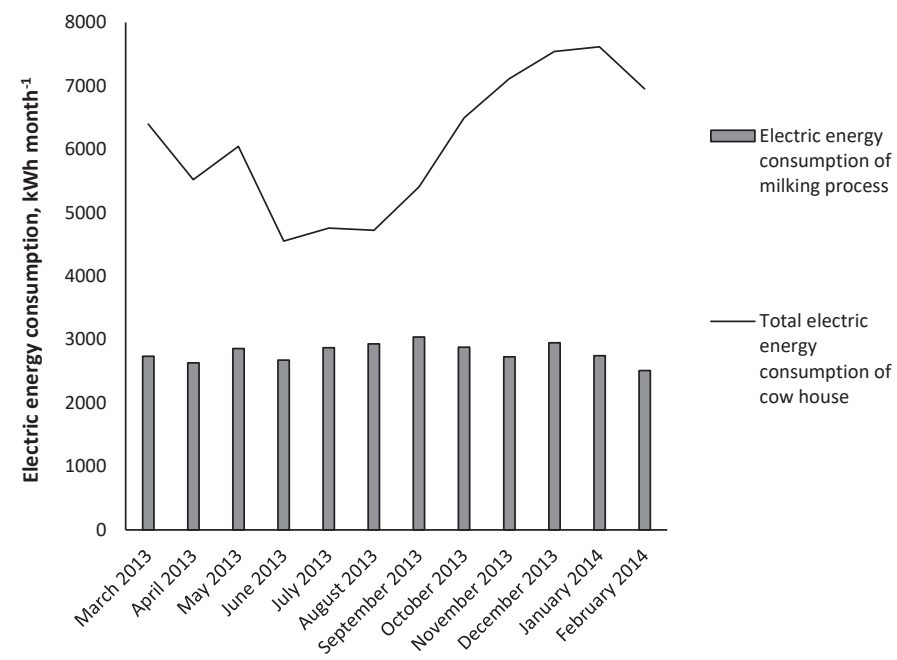

Fig. 1. Monthly electric energy consumption in the cow house and electric energy consumption of the milking process on farm II

\section{Electric energy consumption of milking}

The specific electric energy consumption of milking varied from 9.1 to 29.3 Wh kg-1 milk. Kraatz and Berg (2007, 2009) noted that automatic milking systems often use more electricity compared to conventional systems. Variation in the electricity consumption of milking was largest on farms I and III (RSD $22 \%$ and $18 \%$, respectively). On farm I, the main reason for the large variation in the specific energy consumption of milking is that the heating energy of the AMS system cleaning water was included in the electricity consumption of milking, and it was not possible to separate it in the measurement setup of the study. The cleaning water requirement remains relatively constant, irrespective of the milk yield, which causes the specific energy consumption to vary alongside the milk yield. Previous studies (e.g. Lindgaard Jensen 2009) have shown that water consumption of AMS (Lely A3) was ca. 0.3 I per kg of milk.

Variation in the specific energy consumption of milking was also quite large on farm III. One reason for this could be variation in the milk yield. The milk yield itself should not have a significant effect on the specific energy consumption in conventional milking system, but if the duration of the milking event remains approximately constant as the milk yield decreases, the vacuum pump will run for longer time per milk unit, causing the specific energy consumption to increase. On farm II, the milk yield was quite constant, which may have been the reason for the small variation in the specific electricity consumption of milking.

According to Rasmussen and Pedersen (2004), frequency controlled vacuum pumps consume usually less electricity compared to conventional, non-frequency controlled systems. Vacuum pumps of the milking systems on farms II and III did not utilise variable-frequency drives, and it was thus not possible to examine the effect of this method in this study. Even theoretical assessment could not be made, as there was no information about the average load of the motors of the vacuum pumps.

The monthly electricity consumption of the AMS system was quite constant even when the milk yield varied (Fig. 2). Electricity consumption had three peaks (in April 2013, January 2013 and January 2014), which remained unexplained. Electricity consumption of the AMS correlated weakly with the milk amount produced $(r=0.28)$ and 
the number of cows $(r=0.24)$. This indicates that basic functions (e.g. primary cleaning of the AMS system three times per day) consumed roughly the same amount of energy, irrespective of the number of cows or amount of milk produced. However, the specific energy consumption of milking was lower when the AMS worked at full capacity and it increased when number of cows (and milk yield) decreased. The monthly electricity consumption of milking was lower on farm II than on farm III. The correlation between the milk yield and energy consumption was moderate $(r=0.43)$ on farm II and weak $(r=0.24)$ on farm III.

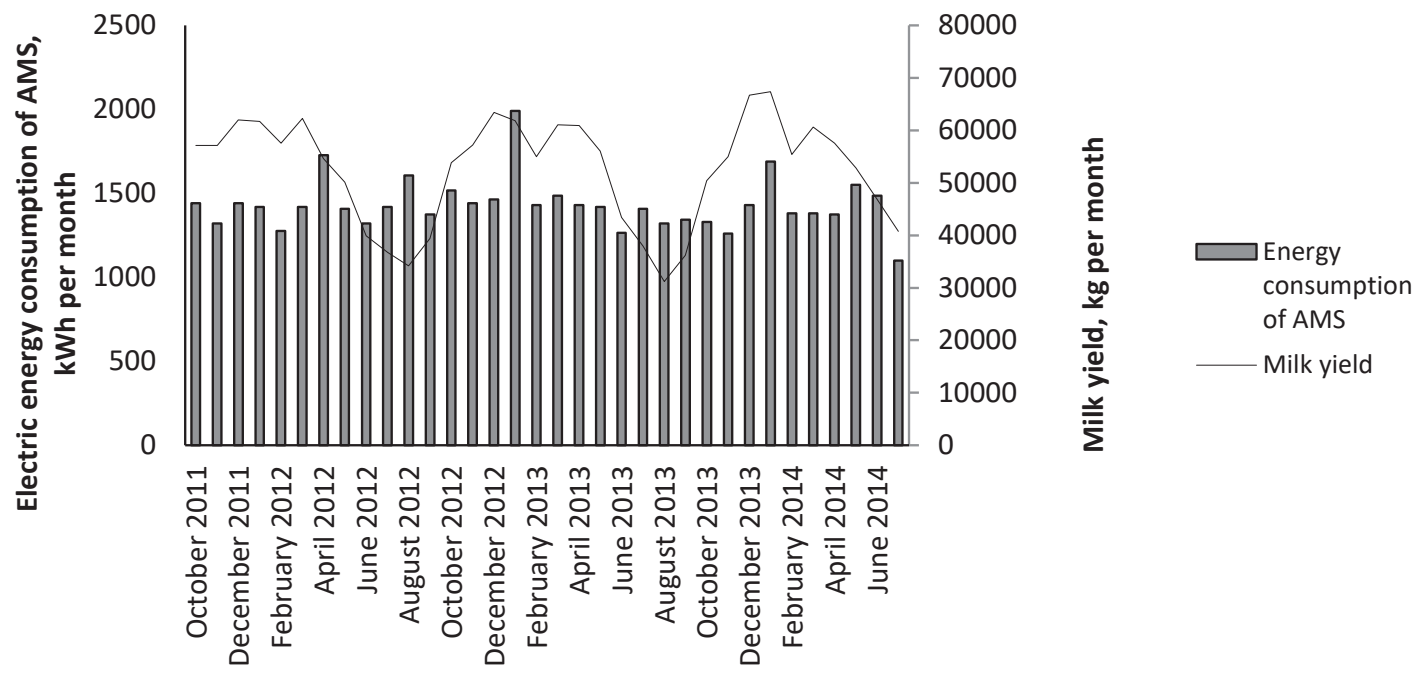

Fig. 2. Monthly electric energy consumption of the milking robot and milk yield with the robot

\section{Electric energy consumption in milk cooling}

The average specific electric energy consumption of milk cooling varied between the farms from 18.5 to $24.9 \mathrm{Wh}$ $\mathrm{kg}^{-1}$ milk. The monthly variation in the specific electricity consumption of milk cooling was relatively equal on all farms with the RSD of $6.0 \%-8.6 \%$. One reason for the lowest energy consumption in milk cooling on farm II was heat recovery from the refrigeration system. The heat recovery system transfers part of the heat energy to the water boiler, instead of the tank room air, which lowers the temperature in tank room and allows the refrigeration system to work more efficiently.

Figure 3 presents the electric energy consumption by the refrigeration system of the bulk milk tank, together with the heat energy extracted from milk and the tank room temperature on farm I. The amount of heat energy extracted from milk is directly proportional to the milk yield (see Equation 2), which is, in turn, nearly directly proportional to the temperature of the tank room, unless pre-cooling, heat recovery, extra ventilation or some other method is applied to lower the tank room temperature. In January 2014, some event led to a decrease in the temperature of the tank room from $35^{\circ} \mathrm{C}$ to $17^{\circ} \mathrm{C}$; the doors had possibly been left open during maintenance. This reduced the electricity consumption of the milk cooling system by nearly 40\%, from a peak value of $64 \mathrm{kWh}$ $\mathrm{d}^{-1}$ to $40 \mathrm{kWh} \mathrm{d}^{-1}$, while the milk yield remained nearly constant during the same period.

The average total COP (cooling \& retaining the temperature) for the refrigeration system on farm I was 1.7. This is relatively poor value for a COP of the milk refrigeration system, as for example Corscadden et al. (2014) reported the COP of 2.17 as an average of measured values from several farms. The low average COP value on farm I was most likely caused by the high temperature in the tank room, which also increases heat conduction from the room into the tank, causing an additional cooling requirement. In January 2014, during the sudden drop in the tank room temperature, the total COP of the cooling system was at highest 2.3. The milk yield varied during the year and was lowest in the summer months, when the cows were on the pasture (Fig. 3). The energy consumption of the bulk milk tank was obviously lowest during this period. 


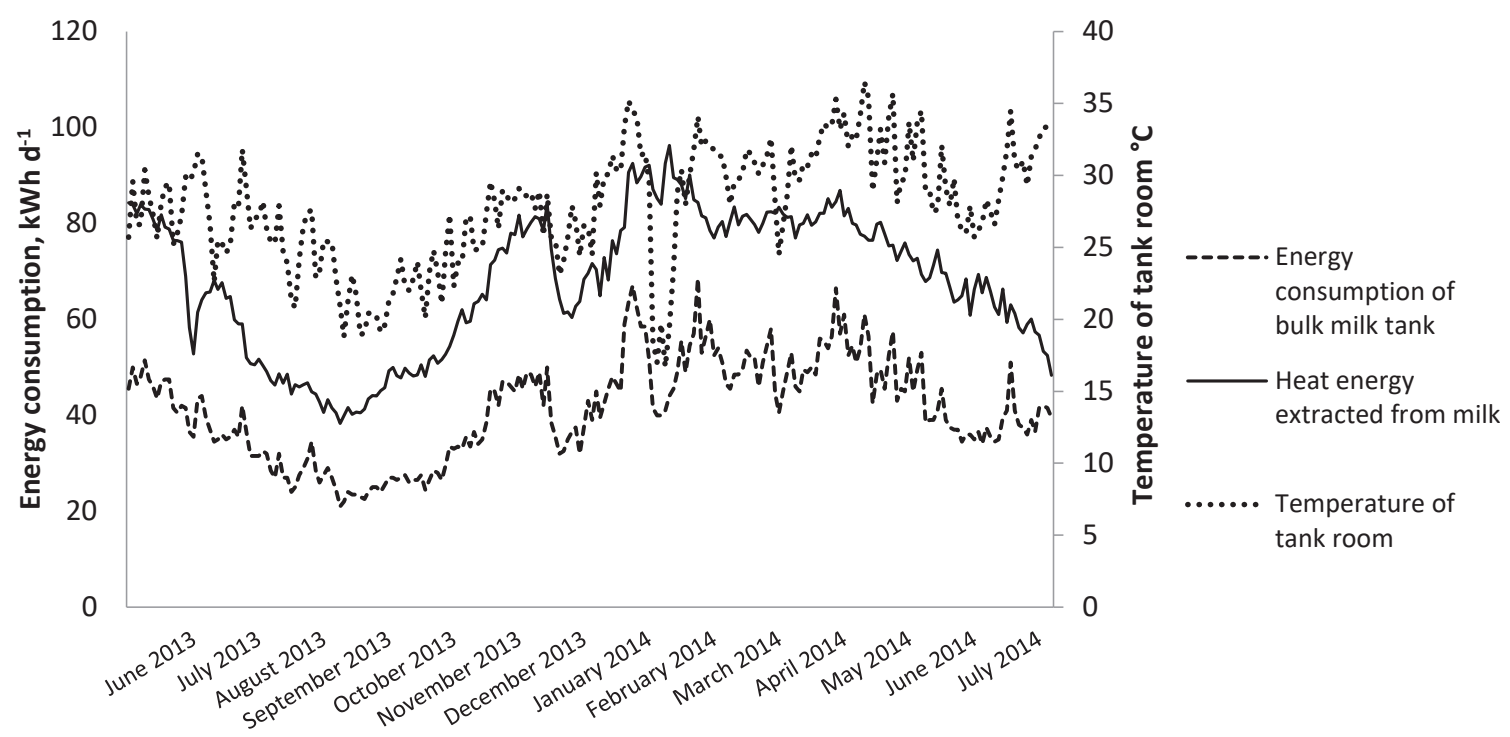

Fig. 3. Daily electricity consumption of the milk tank refrigeration system, amount of heat energy extracted from milk and temperature of the tank room on farm I from May 2013 to June 2014

Figure 4 presents the correlation between the temperature of the tank room and the COP of the bulk milk tank refrigeration system. The COP of the cooling system and temperature of the tank room had a strong negative correlation $(r=-0.79)$. When the milk yield increased, more heat was released to the room and more electricity was needed to cool the milk. This caused an increase in temperature of tank room, and the energy required by the refrigeration process consequently increased, causing a reduction in the COP. The temperature of the tank room on farm I was high $\left(>25^{\circ} \mathrm{C}\right)$ for most of the year, which increased the electricity consumption of the refrigeration system. The highest COP figures in Figure 4 represent the situation in January 2014, during the period of the sudden drop in the tank room temperature (Fig. 3).

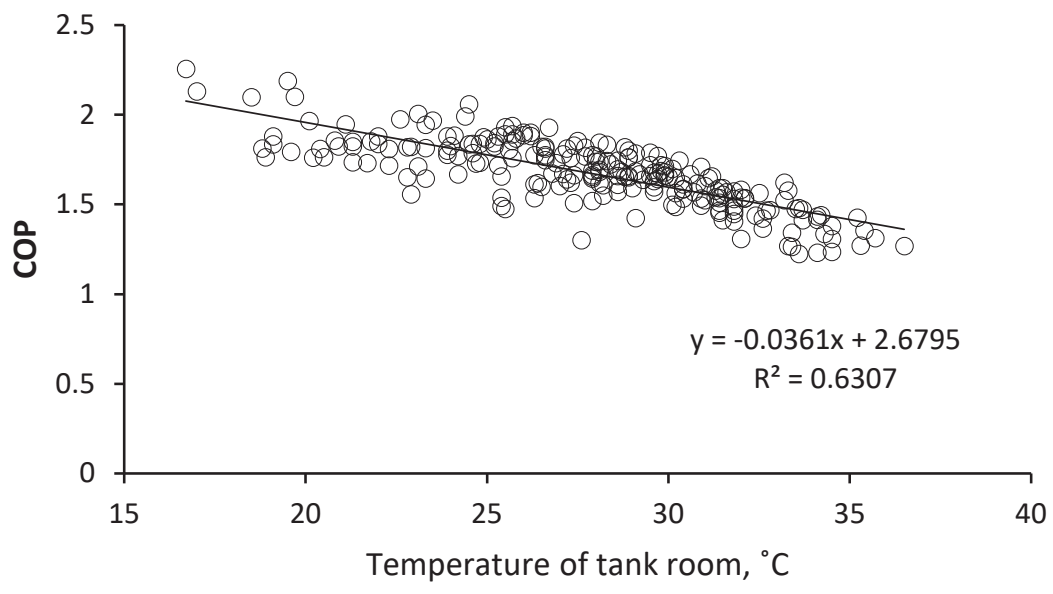

Fig. 4. COP of the refrigeration system with respect to the temperature of the tank room on farm I, and the linear regression model for the COP

\section{Electric energy consumption of water heating}

The specific electricity consumption of water heating varied from 9.7 to $22.8 \mathrm{Wh} \mathrm{kg}^{-1}$ milk between the farms. Farm III used more than twice the amount of electric energy for water heating, with respect to unit of produced milk, compared to farm II. Hot water consumption was not measured, and it is therefore impossible to state exactly what caused this difference. However, heat recovery from milk cooling in farm II can be assumed to be responsible for a major part of this difference. The electricity consumption of water heating was lower on farm I compared to the other farms, because the electric energy consumption of heating the cleaning water of the AMS system was included in that of milking. Hot water was only produced for cleaning the bulk milk tank on farm I. 


\section{Potential to reduce electric energy use in the milking process}

According to the measurements in the present study, milk cooling causes the highest energy consumption in the milking process, followed by heating of cleaning water (apart from the farm I, where the cleaning water for the AMS was included in the energy consumption of milking). Milk cooling and water heating also offer the most significant potential to reduce electric energy consumption in the milking process, since several suitable methods and technologies exist. The following methods were chosen for closer examination: 1) reducing the temperature in the tank room, or more specifically, around the condenser of the refrigeration system, 2) pre-cooling milk with cool water and 3) heat recovery the from milk cooling process for heating the cleaning water (Brooks 1989, Peebles et al. 1994, Manninen and Nyman 2003, Turunen 2013).

Figure 4 clearly indicates that the high temperature of the tank room, where the condenser of the refrigeration system is usually located, causes a significant increase in the energy consumption of milk cooling. Figure 5 presents the coefficient of performance for the cooling process ( $C O P_{\text {cooling }}$ ) according to the theoretical Carnot process in Equation 3 at the end of the cooling process, when the milk temperature is $4{ }^{\circ} \mathrm{C}$. According to Figure 5 , the theoretical maximum COP is ca. 2.5 times better at a room ( = heat sink) temperature of $15{ }^{\circ} \mathrm{C}$, compared to a room temperature of $\mathrm{ca} .30^{\circ} \mathrm{C}$. In practice the COP is approximately one order of magnitude lower than the Carnot COP, but with similar behaviour. Additionally, the COP constantly changes throughout the process, depending on the temperature difference, which causes the relatively linear shape of the COP curve in Figure 4.

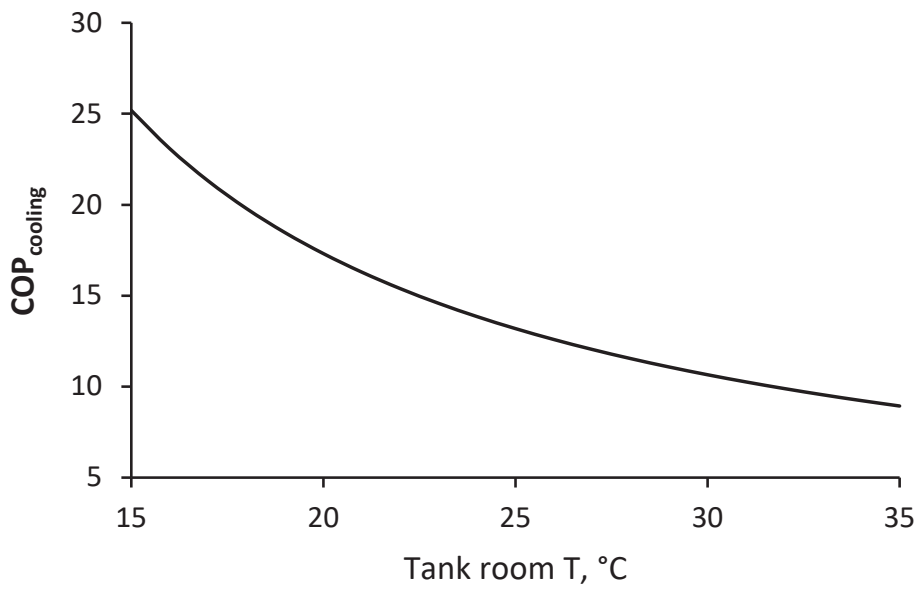

Fig. 5. Theoretical maximum COP $\left(\mathrm{COP}_{\text {cooling }}\right)$ in the Carnot process, with respect to the tank room temperature, at the end of the cooling process (milk temperature $=4^{\circ} \mathrm{C}$ )

The average temperature of the tank room on farm I was $28^{\circ} \mathrm{C}$. When the linear regression model from Figure 4 $(y=-0.0361 x+2.6795)$ is applied to calculate the average COP, the result is ca. 1.7 , which was also the actual average value of the COP on farm I. According to the model, lowering the tank room temperature to $20^{\circ} \mathrm{C}$ would raise the COP to ca. 2.0. This could be easily accomplished by improving the ventilation of the tank room. Further benefit could be achieved by placing the condenser outside. With an average outdoor temperature of, for example $10^{\circ} \mathrm{C}$, the COP would then be 2.3. This would reduce the average energy consumption of milk cooling process on farm I by ca. $30 \%$. The average yearly temperature in southern Finland is around $4-5{ }^{\circ} \mathrm{C}$ (Finnish Meteorological Institute 2017). However, a simulation with daily temperature variation throughout the year, instead of using average values, would be required to receive a more accurate information of the energy saving potential with this method.

Pre-cooling milk with cool water reduces the temperature of the milk before it enters the bulk milk tank and thus reduces the final cooling requirement. If the milk temperature is $36^{\circ} \mathrm{C}$, the temperature of well water is $6{ }^{\circ} \mathrm{C}$ and the heat transfer efficiency of the heat exchanger is $70 \%$, the temperature of milk after pre-cooling will be $15^{\circ} \mathrm{C}$, assuming that the flow of either fluid is equal (max. $\Delta \mathrm{T}=30^{\circ} \mathrm{C}$, with $70 \%$ efficiency $\Delta \mathrm{T}=21^{\circ} \mathrm{C}$ ). The difference in the specific heat capacity between milk and water is small and it was neglected in this analysis. The final cooling requirement is thus only $11^{\circ} \mathrm{C}$. As only a part of heat is released into the tank room air, the COP of the refrigeration system should be satisfactory, despite the lower initial temperature of milk after pre-cooling. If the average COP of 1.7 on farm I is used in the calculation, the electricity requirement in final cooling from $15{ }^{\circ} \mathrm{C}$ to $4{ }^{\circ} \mathrm{C}$ is, 
according to Equations 1 and 2,7 Wh kg-1 milk. Additional energy requirement of water pumping due to the milk pre-cooling is ca. $10 \mathrm{kWh}$ per cow per year (Turunen 2013), which equals to ca. $1.2 \mathrm{Wh} \mathrm{kg}^{-1} \mathrm{milk}$. The combined energy consumption is thus $8.2 \mathrm{Wh} \mathrm{kg}^{-1}$ milk. This means an energy saving of more than $60 \%$ in milk cooling, compared to the current energy consumption value of $22 \mathrm{Wh} \mathrm{kg}^{-1}$ milk on farm I.

Even larger energy savings are possible; according to Turunen (2013) milk can be cooled to within $1-2{ }^{\circ} \mathrm{C}$ of the well water temperature by pre-cooling. With a milk temperature of, for example, $10^{\circ} \mathrm{C}$ after the pre-cooling (heat transfer efficiency ca. 87\%), the energy consumption of final cooling $\left(\mathrm{W}_{\mathrm{c}}\right)$ would only be ca. $4 \mathrm{Wh} \mathrm{kg}^{-1} \mathrm{milk}$, added with $1.2 \mathrm{Wh} \mathrm{kg}^{-1}$ for water pumping (Fig. 6). This corresponds to an electric energy saving of $76 \%$ (17 Wh kg-1 milk) in milk cooling, or more than $25 \%$ in the whole milking process, compared to the current situation on farm I.

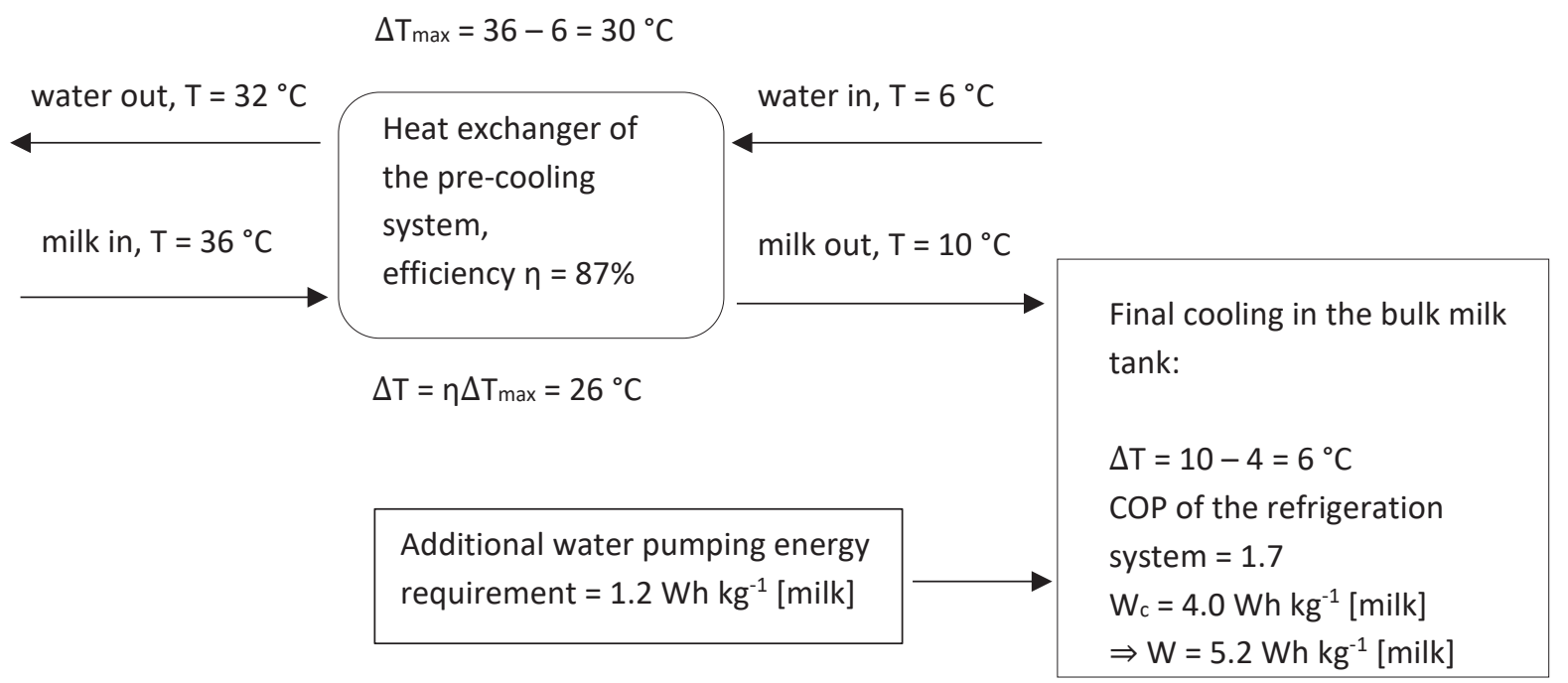

Fig. 6. Effect of milk pre-cooling system on the energy consumption of milk cooling with heat transfer efficiency of $87 \%$. COP of the refrigeration system was assumed to be the same as the measured average value on farm I.

Pre-cooling of milk requires a large amount of cool water, which can be used as drinking water for the cows. The system thus requires a large container where the water can be stored until it is used. According to some studies, pre-warming of drinking water also improves the milk yield of dairy cows (Turunen 2013). In practice the drinking water requirement of cows is considerably larger than the milk yield, and the water flow used in pre-coolers is usually twice as large as the milk flow. This ensures efficient pre-cooling and limits the temperature rise of the water, reducing the risk of microbial infestation in the water (Turunen 2013). Even though the milk pre-cooling system enables significant energy savings compared to the conventional system, it requires also investments, and the profitability must be evaluated case by case.

Recoverable heat energy is limited by the hot water requirement and limited temperature rise of water, caused by a decreasing COP of the refrigeration system when the temperature difference grows excessively. When the typical heat transfer efficiency of $50 \%$ is used, the recoverable heat energy is ca. $18 \mathrm{Wh} \mathrm{kg}^{-1} \mathrm{milk}$, according to Equation 2. Electricity consumption of water heating was on average ca. $13 \mathrm{Wh} \mathrm{kg}^{-1}$ milk lower on farm II, where heat recovery was used, compared to farm III. This figure deviates from the theoretical result, but the difference may also be caused by a difference in hot water consumption per milk unit between the farms.

As stated in the materials and methods -chapter, the use of milk pre-cooling and heat recovery from the milk together is not necessarily rational, since pre-cooling reduces the amount of recoverable heat energy and thus weakens the COP in water heating. One possible solution for this problem would be to use a cascade heat pump in milk cooling and water heating in combination with milk pre-cooling. Cascade heat pumps include two individual heat pump cycles, which are connected with a cascade heat exchanger (Park et al. 2013). Heating the water in two phases with a cascade heat pump results in a moderate temperature difference in each cycle, which enables a better COP with a large temperature rise in water heating (Jung et al. 2013, Park et al. 2013). The milk pre-cooler should then be designed to remove such an amount of heat energy from milk that the remaining part would be sufficient for heating the cleaning water. Figure 7 presents the combined milk cooling and water heating scheme. 


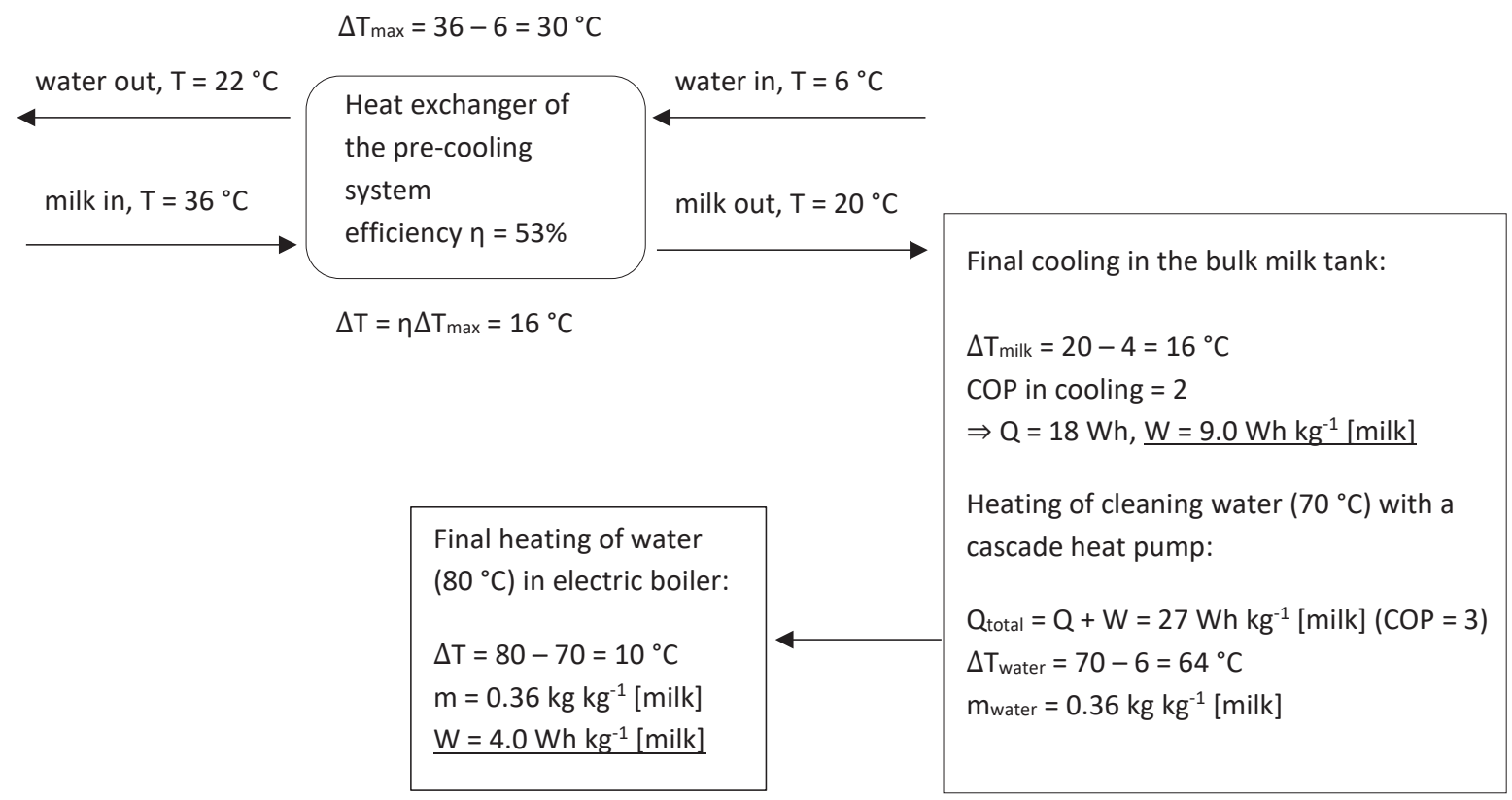

Fig. 7. Scheme of combined milk cooling and water heating system with partial pre-cooling of milk and heat recovery from the final cooling for heating the cleaning water with a cascade heat pump. System could produce ca. one third of hot water of the milk amount produced with total electricity consumption of ca. 14 Wh per one kilogram of milk.

In Figure 7, COP in cooling is assumed to be 2 (e.g. Corscadden et al. 2014) used COP of 2.17 for the refrigeration system). The electricity used by the compressor is converted to heat energy, and when this energy is also transferred to water, the COP in water heating would be 3, which is achievable with cascade heat pumps (Park et al. 2013). The system could hence produce ca. $0.36 \mathrm{I}$ of $70^{\circ} \mathrm{C}$ water per one kg of milk with an electricity consumption of $9 \mathrm{Wh} \mathrm{kg}^{-1}$ milk. For example, on farm I, this would be equal to ca. 750 litres hot water per day on average, which is close to the daily hot water requirement of the AMS system (Turunen 2013). Additional heating of this 0.36 I of water to a temperature of $80^{\circ} \mathrm{C}$ would require ca. $4 \mathrm{Wh}$ of electricity, and the total electricity consumption of milk cooling and water heating would thus be $14 \mathrm{Wh} \mathrm{kg}^{-1}$ [milk], when also the additional pumping requirement due to the pre-cooling is considered. For example farm III used $47.7 \mathrm{Wh} \mathrm{kg}^{-1}$ milk of energy for milk cooling and water heating, and this would hence mean energy savings of ca. $70 \%$ in these processes, or more than $50 \%$ in the whole milking process, compared to the initial situation. On farm III, this would account to nearly $28000 \mathrm{kWh}$ per year. $\mathrm{CO}_{2}$ emissions from the use of electricity would accordingly decrease by ca. $6200 \mathrm{~kg} \mathrm{a}^{-1}$.

There is, however, no information about performance and investment costs of the cascade heat pump coolingheating systems in the milking process, since no commercial applications in dairy farming exist. Further research about the suitability and profitability of this technology on dairy farms is therefore required.

\section{Conclusions}

The electric energy consumption of the milking process (milking, milk cooling and heating of cleaning water) on the case farms varied between 37-62 $\mathrm{Wh} \mathrm{kg}^{-1}$ milk. The results from this study were within the range of variation of the figures reported in the literature. On farm I, the largest electricity consuming processes were milking (including heating of cleaning water for the AMS) and milk cooling. On farms II and III, the majority of energy in the milking process was consumed by milk cooling and water heating.

The results from this study indicate that there are several possibilities to achieve moderate to large reductions in energy use. Even relatively simple and low-cost measures, such as improving the ventilation of the tank room or placing the condenser of the refrigeration system outside the building, could result in energy savings of ca. $30 \%$ in milk cooling. More advanced systems, such as milk pre-cooling and heat recovery from milk cooling, or the combinations of these systems, can offer substantial improvements in energy efficiency. As these systems require also investments, the profitability must be evaluated in each case individually. 
Data from the AMS farm indicated that the electricity consumption of the AMS system remained quite constant irrespective of the number of animals or milk yield. It would therefore be advisable to always utilize the full capacity of the milking system, regardless of the type of system. The more milk is produced at the milking station, the smaller is the relative share of energy consumption of cleaning, and the lower the specific energy consumption of the milking process. Additional energy savings in milking could be achieved by utilizing variable-frequency drives in the vacuum pump of the milking machine, or by shortening the milking time with improved management, but these methods were not analysed in this study.

Although the milking process is often the largest electric energy consumer in dairy farming, other electricity consumption must also be taken into consideration. On farm II, where the total energy consumption was measured, roughly half of electricity was consumed in the milking process and the other half somewhere else in the cow house.

\section{Acknowledgements}

This study was performed in two projects: Energy Academy, which was financed by the Rural Development Programme for Main-land Finland 2007-2013, and Karema, which was financed by Technical and Societal Research Foundation (Teknillis-yhteiskunnallinen tutkimussäätiö sr.). Authors present their gratitude to the financiers.

\section{References}

Brooks, L.A. 1989. Electric energy management on dairy farms. In: McFate (ed.). Electrical energy in agriculture. Vol 3. Amsterdam: Elsevier science publishers B.V. p. 93-120.

Corscadden, K.W., Biggs, J.N. \& Pradhanang, M. 2014. Energy efficient technology selection for dairy farms: milk cooling and electric water heating. Applied Engineering in Agriculture 30: 375-382.

Dancey, C. \& Reidy, J. 2004. Statistics without Maths for Psychology: using SPSS for Windows. London: Prentice Hall. 640 p.

Delaval 2016. DeLaval esijäähdytysjärjestelmä. Cited 25 January 2017. http://www.delaval.fi/ImageVaultFiles/id_19058/cf_5/ Esij-hdytysj-rjestelm-.PDF. (in Finnish).

Finnish Energy Authority 2016. Electricity price statistics. Cited 11 January 2017. http://www.energiavirasto.fi/sahkon-hintatilastot Finnish Meteorological Institute 2017. Climate statistics. Cited 22 February 2017. http://en.ilmatieteenlaitos.fi/normal-period

Heimonen, I., Heikkinen, J., Laamanen, J. \& Kivelä, T. 2012. Lypsykarjapihaton luonnollinen ilmanvaihto. VTT Technology 71.174 p. (in Finnish).

Hörndahl, T. 2008. Energy use in farm buildings - A study of 16 farms with different enterprises. Revised and translated second edition. Swedish University of Agricultural Sciences, Faculty of Landscape Planning, Horticulture and Agricultural Science. Report 2008: 8. 69 p.

Jung, H.W., Kang, H., Yoon, W.J. \& Kim, Y. 2013. Performance comparison between a single-state and a cascade multi-functional heat pump for both air heating and hot water supply. International Journal Refrigeration 35: 1431-1441. https://doi.org/10.1016/j. ijrefrig.2013.03.003

Kraatz, S. \& Berg, W.E. 2007. Energy demand for milking dairy cows. ASABE paper No. 074175. 2007 ASAE Annual Meeting. St. Joseph, Michigan: ASABE. p. 12. https://doi.org/10.13031/2013.23273

Kraatz, S. \& Berg, W.E. 2009. Energy efficiency in raising livestock at the example of dairy farming. ASABE paper No. 096715. 2009 Reno, Nevada, June 21 -June 24, 2009. St. Joseph, Michigan: ASABE. p. 19. https://doi.org/10.13031/2013.27271

Lindgaard Jensen, M. 2009. Power and waterconsumption with AMS. FarmTest \# 61 - December 2009. Cited 1 October 2017. http://www.milkproduction.com/Documents/Farmtest61-AMS-UK-web.pdf

Ludington, D. \& Peterson, R.C. 2005. How much energy does your dairy use? Northeast Dairy Business September: 20-21.

Luonnonvarakeskus 2016. Economydoctor. Financial statistics of Natural Resources Institute Finland. Cited 9 January 2017. https://portal.mtt.fi/portal/page/portal/taloustohtori

Manninen, E. \& Nyman K. 2003. Maidonkäsittelyn teknologiaa. MTT:n selvityksiä 15. Cited 2 February 2017.

http://www.mtt.fi/julkaisut/maitokoneet/mtts15.pdf. (in Finnish).

Murgia, L., Caria, M. \& Pezzona, A. 2008. Energy use and management in dairy farms. International conference "Innovation technology to Empower Safety, Health and Welfare in Agriculture and Agro-food Systems", September 15-17, 2008, Ragusa, Italy. Cited 2 February 2017. http://ragusashwa.it/CD_2008/lavori/TOPIC9/orale/MURGIA.pdf

Neuman, L. 2009. Kartläggning av energianvändning på lantbruk 2008, rapport. Borås: LRF-konsult AB. 35 p.

Park, H., Kim, D.H. \& Kim, M.S. 2013. Performance investigation of a cascade heat pump water heating system with a quasi-steady state analysis. Energy 63: 283-294. https://doi.org/10.1016/j.energy.2013.10.019

Peebles, R.W., Reinemann, D.J. \& Straub, R.J. 1994. Analysis of milking center energy use. Applied Engineering in Agriculture $10:$ 831-839. https://doi.org/10.13031/2013.25918

Perttula, J. 2000. Energiatekniikka. Porvoo: WS Bookwell Oy. 204 p. (in Finnish). 
Petroleum \& Biofuels Association - Finland 2016. Consumer prices since year 2000. Cited 11 January 2017. http://www.oil.fi/en/ statistics-1-prices-and-taxes/11-consumer-price-update

Rasmussen, J. \& Pedersen, J. 2004. Electricity and water consumption at milking. Farm Test - Cattle 17. 40 p.

Sanford, S. 2013. Well Water Pre-Coolers. Energy Conservation in Agriculture. University of Wisconsin. http://learningstore.uwex. edu/Assets/pdfs/A3784-03.pdf. Accessed 21 January 2017.

Sonesson, U., Cederberg, C. \& Berglund, M. 2009. Greenhouse gas emissions in milk production. Decision support for climate certification. Accessed 21 October 2014. http://www.klimatmarkningen.se/wp-content/uploads/2009/12/2009-3-milk.pdf.

Tike 2010. Maa- ja puutarhatalouden energiankulutuksen jakautuminen tuotantosuunnittain ja energialähteittäin vuonna 2010. Maatalouden rakennetutkimus, Maatalouslaskenta 2010. (in Finnish).

Tike 2013. Yearbook of Finnish farm statistics. http://stat.luke.fi/sites/default/files/vuosikirja_2013_etukannella.pdf. Accessed 2 February 2017.

Turunen, M. 2013. Energian käyttö ja säästö maidontuotannossa. In J. Ahokas (ed.). Energian kulutus ja säästö karjataloudessa. Maataloustieteiden laitos julkaisuja 27. p. 49-109. (in Finnish).

Upton, J., Humphreys, J., Groot Koerkamp, P.W.G., French, P., Dillon, P. \& De Boer, I.J.M. 2013. Energy demand on dairy farms in Ireland. Journal of Dairy Science 96: 6489-6498. https://doi.org/10.3168/jds.2013-6874 